\title{
A REVISION OF THE
}

\section{PONERINE ANT GENUS PLECTROCTENA F. SMITH (HYMENOPTERA : FORMICIDAE)}

BY

BARRY BOLTON

Pp. 309-338; 1o Text-figures

\author{
BULLETIN OF \\ THE BRITISH MUSEUM (NATURAL HISTORY) \\ ENTOMOLOGY \\ Vol. 30 No. 6 \\ LONDON : 1974
}


the Bulletin of the British Museum (NATURAL HISTORY), instituted in I949, is issued in five series corresponding to the Departments of the Museum, and an Historical series.

Parts will appear at irregular intervals as they become ready. Volumes will contain about three or four hundred pages, and will not necessarily be completed within one calendar year.

In I965 a separate supplementary series of longer papers was instituted, numbered serially for each Department.

This paper is Vol. 30 No. 6 of the Entomological series. The abbreviated titles of periodicals cited follow those of the World List of Scientific Periodicals.

World List abbreviation Bull. Br. Mus. nat. Hist. (Ent.)

(C) Trustees of the British Museum (Natural History), I974 


\title{
A REVISION OF THE \\ PONERINE ANT GENUS PLECTROCTENA \\ F. SMITH (HYMENOPTERA : FORMICIDAE)
}

\author{
By B. BOLTON
}

CONTENTS

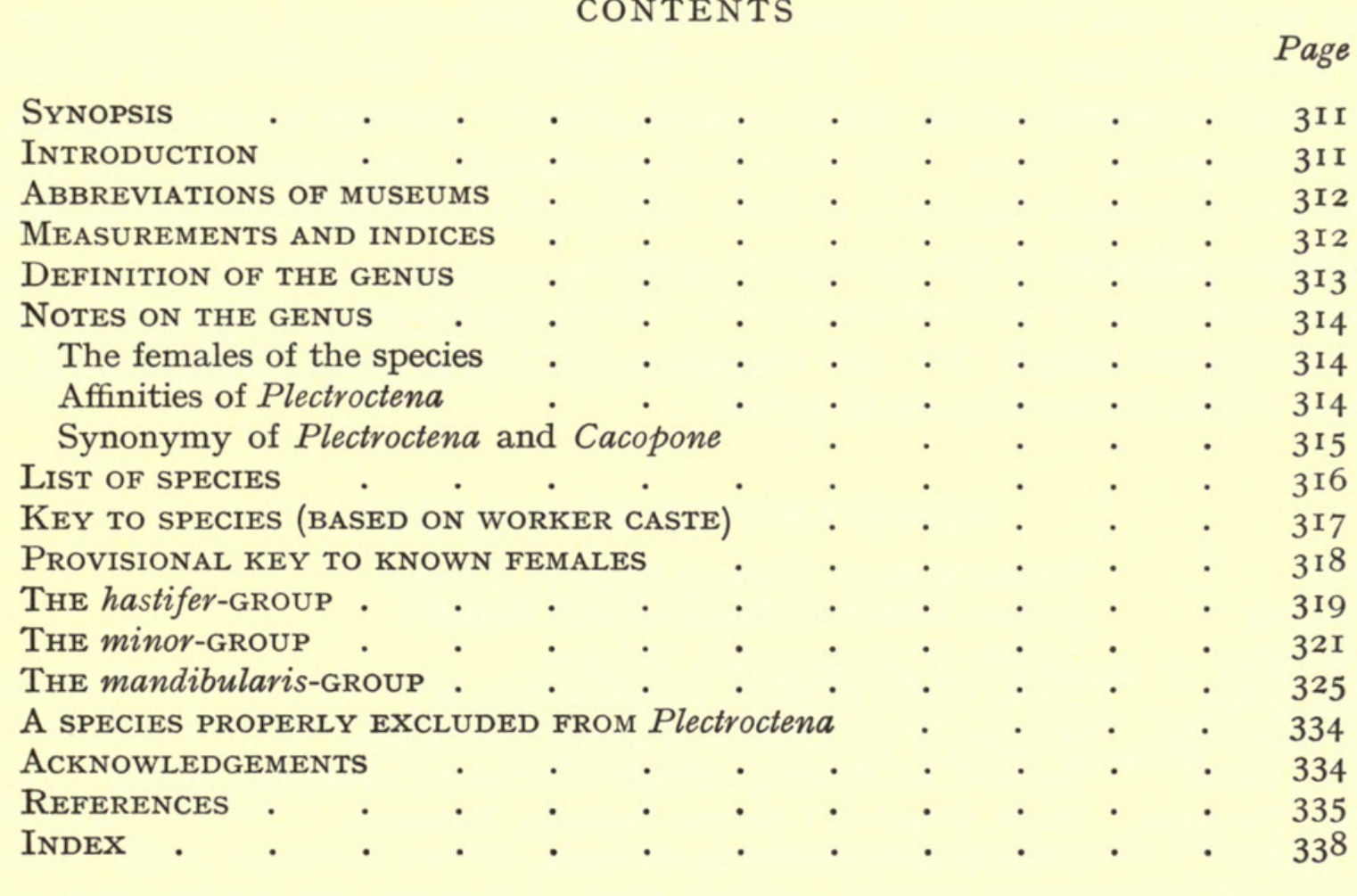

\section{SYNOPSIS}

The ponerine ant genus Plectroctena is revised. Three new species are described and eight new synonyms established. Keys are presented for the worker caste and for the known females. The affinities of the genus are discussed and the constituent species described. The genus Cacopone is synonymised with Plectroctena. The species mabirensis Arnold is transferred to Psalidomyrmex André, establishing a new combination. Known biological information on the species is included.

\section{INTRODUCTION}

THE sixteen known species of this small ponerine genus are restricted to the Ethiopian region. The majority are found only in the rain forest zones of West and Central Africa but a few species are found in the southern and eastern parts of the continent, and one is apparently restricted to the offshore Principe Island in the Gulf of Guinea. One species of central African origin has been recorded from the island of Fernando Po (Eidmann, I944).

Nests are made directly into the earth (Arnold, I9I5) or are built in extremely 
rotten or collapsed logs. A dealate female of one species, minor Emery, has been found in a fallen and rotting carton nest of a species of Crematogaster Lund.

Foraging is subterranean or cryptic and workers are often found beneath the bark of rotting logs. The workers forage singly or in small processions of two or three individuals. The main food of the genus appears to be millepedes and beetles (Arnold, I9I5) although some species may also feed on termites and other soft-bodied arthropods which inhabit rotten wood. The feeding habits of the smaller and completely subterranean species are not known.

Previous publications on the genus are mostly represented by scattered descriptions of new forms and notes on distribution. Arnold (I9I5) gave notes on the South African species and Wheeler (I922a) included a few notes and comments on some of the central African species. A review of the genus was undertaken by Santschi (I924) which was little more than a vehicle for the description of numerous new, mainly infraspecific forms. His text is littered with contradictions and mistakes and the key presented therein is of little value. No attempt was made to ascertain the variation inherent in the commoner species.

The present paper is thus an attempt to delimit the known species more accurately and to give some insight into the variation, distribution and known habits of the members of this interesting small genus.

\section{ABBREVIATIONS OF MUSEUMS}

$\mathrm{BMNH}$

IE, Naples

IE, Bologna

MCSN, Genoa

$\mathrm{MCZ}$, Cambridge

MNHU, Berlin

MRAC, Tervuren

NM, Basle
British Museum (Natural History), London.

Istituto di Entomologia Agraria, Naples.

Istituto di Entomologià, Bologna.

Museo Civico di Storia Naturale, Genoa.

Museum of Comparative Zoology, Cambridge.

Museum für Naturkunde der Humboldt-Universität, Berlin.

Musée Royal de l'Afrique Centrale, Tervuren.

Naturhistorisches Museum, Basle.

\section{MEASUREMENTS AND INDICES}

Total Length (TL). The total outstretched length of the individual, from mandibular apex to the gastral apex.

Head Length (HL). The straight-line length of the head in perfect full-face view, measured from the mid-point of the anterior clypeal margin to the posteriormost point of the occipital margin (i.e. in species with a strongly concave occipital margin the head length is measured to the mid-point of a line connecting the posterolateral projections).

Head Width (HW). The maximum width of the head measured behind the eyes in full-face view.

Cephalic Index (CI). $\frac{\mathrm{HW} \times \text { Ioo }}{\mathrm{HL}}$

Mandibular Length (ML). The straight-line length of the mandibular blade measured from the apex to the point at which the outer margin meets the clypeus. 
Mandibulo-Cephalic Index (MI). $\frac{\mathrm{ML} \times \text { Ioo }}{\mathrm{HL}}$

Scape Length (SL). The straight-line length of the scape, excluding the basal constriction or neck.

Petiole Height $(\mathrm{PH})$. The height of the petiole measured in profile from the apex of the ventral process vertically to a line intersecting the dorsalmost point of the node.

Petiole Length (PL). The length of the petiole node from the anterior process to the posteriormost point of the tergite, where it surrounds the gastral articulation.

Lateral Petiole Index (LPI). $\frac{\mathrm{PH} \times \text { I00 }}{\mathrm{PL}}$

Dorsal Petiole Width (DPW). The maximum width of the petiole in dorsal view.

Dorsal Petiole Index (DPI). $\frac{\mathrm{DPW} \times \text { I00 }}{\mathrm{PL}}$

Ocular Diameter. The maximum diameter of the eye measured across the circumocular groove or impression.

All measurements are expressed in millimetres.

\section{DEFINITION OF THE GENUS}

\section{PLECTROCTENA F. Smith}

Plectroctena F. Smith, I858 : ror. Type-species: Plectroctena mandibularis F. Smith, loc. cit., by monotypy [= Ponera caffra Spinola, I853: 70 (attributed to Klug), nomen nudum].

Cacopone Santschi, I9I4b:325. Type-species: Cacopone hastifer Santschi, loc. cit., by monotypy. Syn. n.

Worker. Black, brown or reddish ponerine ants belonging to the tribe Ponerini. Monomorphic, with notable size variation in some species. Lifeway subterranean or cryptic with nest sites in the earth or in rotten wood. Size ranges from medium to very large (TL $5.6-23.5$ ).

Mandibles elongate, linear, somewhat curved at least in the distal half, ML $>0.5 \mathrm{HL}$ (measured range of MI 70-95). Mandibular blades edentate or armed with one or two teeth and with a longitudinal groove on the inner half of the dorsal surface which runs part or all the length of the blade. Mandibular articulation associated with a marked excavation of the anterior margin of the head in front of the eye. Palp formula of maxillary 3-, labial 4-segmented (dissections of conjugata, cristata, mandibularis, minor, strigosa) or with the labial palp 2segmented (subterranea). Antennae I2-segmented. Eyes small, minute or absent; when present they are situated anterolaterally upon the head, usually on the dorsal surface and are surrounded by a circumocular groove or impression. Median portion of clypeus short, vertical, overhung by the strongly developed lobes of the frontal carinae. Dorsum of alitrunk with a single developed suture, the promesonotal. Track of metanotal groove faintly visible in individuals of some species. Propodeal declivity bordered on each side by a raised ridge or lamina which sometimes also extends across the dorsum. Femora of middle and hind legs with a mediodorsal thin strip of cuticle or a shallow groove which extends for at least the basal one-third of the length of the femur. Middle and hind tibiae each with a single pectinate spur, the lateral spur absent. Pretarsal claws simple. Petiole a node of variable shape; gaster very strongly constricted between the first and second segments.

Female. As worker but somewhat larger; either alate with fully developed flight sclerites 
or ergatoid. Ocelli present in alate forms, reduced or vestigial in ergatoids. Eyes larger than in workers.

The known females are discussed below.

Male. Mandibles very reduced, edentate, short, roughly rectangular in shape and apparently failing to meet apically at full closure. Palp formula of maxillary 5 or 6 segments, labial 4 segments (mandibularis), the apical and penultimate maxillary palpomeres fused or separate (degree of fusion is variable and may be greater in one palp than the other on the same specimen). Antennae I3-segmented, very long and filiform. Scape and first funicular segment short, their combined length equal to or less than the length of the second funicular segment. Clypeus well developed, broad. Frontal carinae strongly developed into triangular or rounded lobes which are elevated at an angle of about 45 degrees. Eyes large, ocelli well developed. Pronotum not overhung by mesoscutum in front, the latter with notauli and parapsidal furrows present. Scutellum swollen and somewhat dome-shaped and prominent in profile, commonly with a median longitudinal impression dorsally. Legs with femora lacking the mediodorsal thin strip or groove, the tibiae of the middle and hind legs each with a single pectinate spur. Pretarsal claws with a small median tooth. Hind wing with anal lobe present. Genitalia rectractile, gonopalpi present. Parameres thick and blunt, bowed outwards, curving towards one another apically. Digitus of volsella right-angled, with the apical portion thickened and equipped with numerous minute, dentiform structures on the side facing the cuspis; the latter bowed toward the digitus. Aedeagus a pair of large plates, the ventral portions of which are strongly sclerotized and serrate, the teeth recurved.

\section{NOTES ON THE GENUS}

The FEMALES OF THE SPECIES.

Of the I6 described species females of II are known or are associated for the first time in this paper. Of these II, four are ergatoid, the remainder being normal alate forms with developed flight sclerites. The species with ergatoid females include cristata, dentata, conjugata, and the type-species mandibularis; females are unknown for anops, hastifer, laevior, macgeei and strigosa; the rest have alate queens.

Wheeler (I922a: 88) described a third form of female as apterous and attributed it to minor. His description is very short, but from the size and colour of the individual it seems certain that his specimen is not minor. I have not seen the specimen but it may represent an otherwise unknown species as it is not easily applicable to any presently known form. I would not be surprised if a reexamination of this queen reveals that its wings have been lost in quite the normal manner.

Santschi (I924: I55) stated that the female of gestroi is ergatoid, which is not the case, and gave latinodis as being apterous. I have examined the syntype and a second female of latinodis and find that the wings have been lost in the normal manner and that remnants of the detached forewings are visible, projecting from beneath the tegulae.

Affinities of Plectroctena.

Emery (I9II) grouped Plectroctena with the genera Trapeziopelta Mayr 
Myopias Roger and Psalidomyrmex André in a subtribe Plectroctenini of tribe Ponerini. Forel (I9I7) retained this arrangement and added Cacopone to the group as Santschi (IgI4b) had already stated that this genus was related to Psalidomyrmex and Myopias. Santschi (I924) added Promyopias Santschi to the list of genera in the subtribe and it has remained as such to the present day.

The characters given to link these genera were always tenuous and seemed to rest, rather uneasily, upon the fact that the members, except Psalidomyrmex, possessed elongate or linear mandibles. Emery (IgII) characterised his subtribe by sculpturation, which is so variable amongst member-species as to be meaningless, and by the development of the lateral tibial spurs which were given as rudimentary or absent. Brown (I963) has pointed out that this character was much overemphasized in the past but amongst the genera at present under discussion it is of use in separating them. Thus, Trapeziopelta, Myopias and Promyopias each have a recognizable lateral tibial spur in addition to a strongly developed median spur, whereas in the remainder this lateral spur is lacking or is indistinguishable from the surrounding setae.

Observation of the species in these genera implies that Myopias and Trapeziopelta are closely related and are derived from the Pachycondyla-Bothroponera complex of the tribe Ponerini, whereas the true affinities of Promyopias appear to lie with Centromyrmex as the median spurs of the middle pair of legs are reduced whilst those of the hind legs are fully developed. Also the extensor surfaces of the tibiae and basal tarsal segments of the mid legs are equipped with spines and the gaster is not constricted behind the first segment.

Of the three remaining genera, Cacopone is now known to be a synonym of Plectroctena (see note 3, below) and Psalidomyrmex appears as the genus most closely related to Plectroctena. These last two share the same form of alitrunk, node and gaster in the worker and female castes and have the same odd reduction of palpal segments, where the labial palps have more segments than the maxillaries; the most common palp formula in both genera being maxillary 3-, labial 4-segmented. The males are remarkably similar and are separated only by the absence of notauli in Psalidomyrmex, but in the workers and females the unique mandibular development and the presence of femoral dorsal grooves in Plectroctena quickly separate the genera.

The origins of both Plectroctena and Psalidomyrmex appear to lie in the genus Bothroponera but evidence in support of this assumption is as yet incomplete. It is, however, probably safe to say that their origins differ from those of Myopias and Trapeziopelta.

Thus the subtribe Plectroctenini is spurious, being merely an assemblage of long-mandibulate forms of tribe Ponerini placed together for the sake of convenience.

\section{Synonymy of Plectroctena And Cacopone.}

The genus Cacopone was founded upon a single specimen by Santschi (I9I4b) who considered it to be 'between Psalidomyrmex and Myopias'. Later, in his review of Plectroctena, Santschi (I924) stated that this genus was very close to Cacipone 
and separated the latter on the shape of its mandibles and the fact that 'the articulatory emargination of the anterior angle of the head (is) missing'.

This statement corresponds to the figure of $C$. hastifer given by Santschi in the original description, where no emargination is shown, but flatly contradicts the statement on lines $2-3$ of the original description where the clypeus is said to be 'emarginate at the mandibular insertions'.

A specimen in the BMNH collection from Tafo, Ghana (only a short distance from the type-locality of $C$. hastifer) fits the original description perfectly and only fails to match the figure as the articulatory emarginations are well developed. It was concluded that the figure was inaccurate but had been used by Santschi as his reference point for Cacopone when working on his review of Plectroctena, as the holotype of hastifer was at that time no longer in his possession but had been deposited in the IE, Naples along with the rest of the Silvestri material from which it originally came.

Only the specialized shape of the mandibles remained to separate Cacopone from Plectroctena but this character, weakened by the discovery of a second, hastiferlike species with more normal mandibles is insufficient evidence for retaining the genus, and it is consequently relegated to the synonymy of Plectroctena.

\section{LIST OF SPECIES}

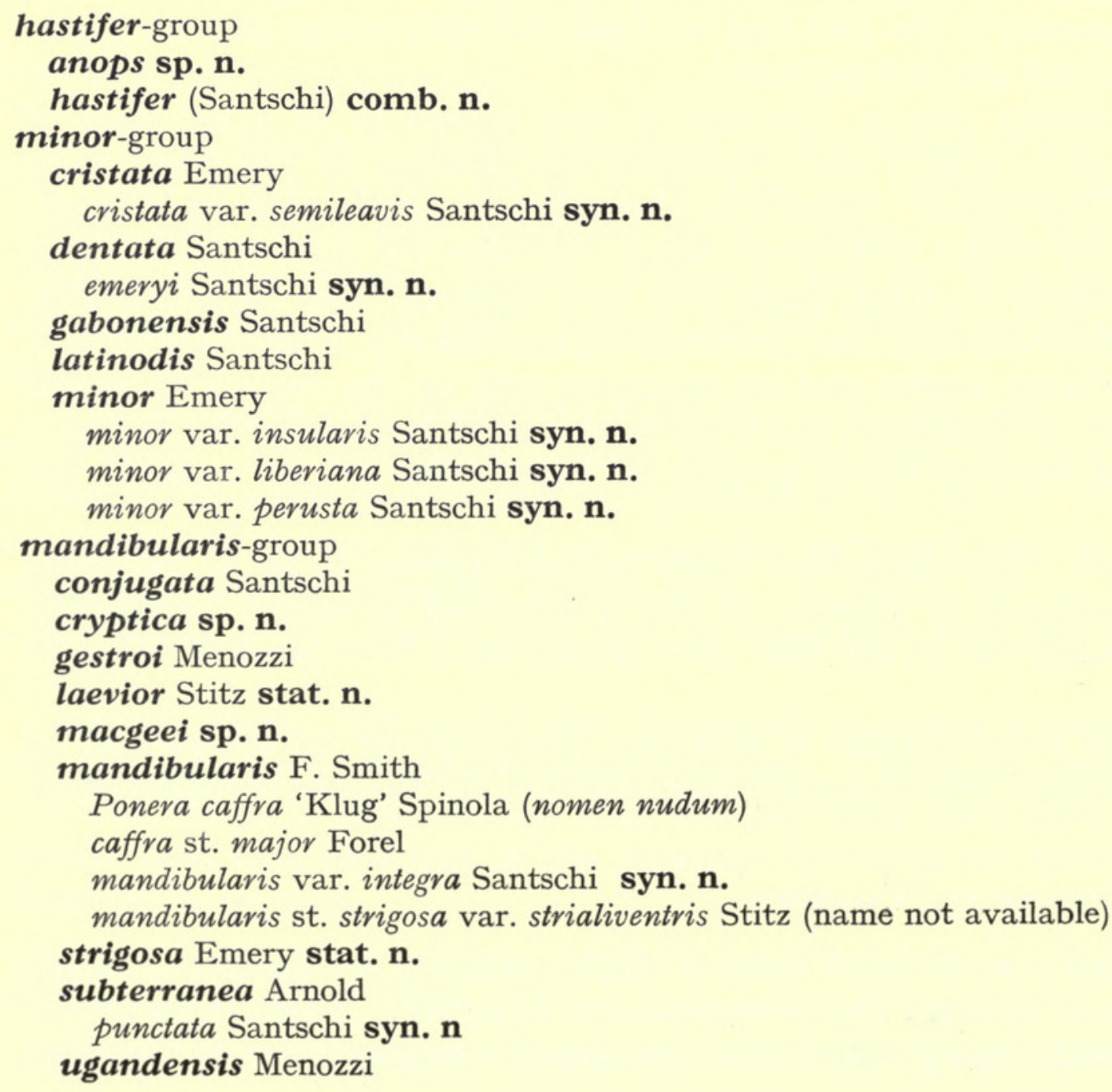




\section{KEY TO SPECIES}

\section{(Based on worker caste)}

Note: the worker of ugandensis is not known.

I Apical half of each mandibular blade swollen; basal tooth absent (Text-fig. 2). Head relatively narrow, CI $<80$. Propodeal laminae continuous around dorsum of declivity

- Apical half of each mandibular blade not swollen; basal tooth usually present (Textfig. 3). Head relatively broad, CI $>85$. Propodeal laminae if present confined to lateral portions of declivity, not continuous around the dorsum

2 Dorsal surfaces of head, alitrunk, petiole and first gastral tergite with numerous erect hairs. Eyes present, minute. Node of petiole relatively long and low in profile, LPI $<75$. (Ghana) .

hastifer (p. 320)

- Dorsal surfaces of head, alitrunk, petiole and first gastral tergite without erect hairs. Eyes absent. Node of petiole relatively higher in profile, LPI $>85$. (Ghana)

3 First gastral tergite with an anteriorly located transverse groove or impression which may run the width of the tergite or may be reduced to the central onequarter of the width of the segment

- First gastral tergite without a transverse groove or impression anteriorly . .

4 Ventral surfaces of the head and usually also the sides of the head, at least below and behind the eyes, with the spaces between punctures finely striate. Funicular segments $3-4$ as long as, or longer than broad

- Ventral surfaces of the head and sides of head below and behind the eyes with the spaces between punctures smooth and shining. Funicular segments 3-4 broader than long, usually markedly so

Very large species, $\mathrm{HL}>_{4} \cdot \mathrm{o}$, with relatively very long mandibles, $\mathrm{MI}>90$. Ocular diameter 0.46 or more. (Cameroun, Zaire, Kenya) . . . . . cristata (p. 32I)

- Smaller species, $\mathrm{HL}<{ }_{4} \cdot 0$, with relatively shorter mandibles, $\mathrm{MI}<90$. Ocular diameter 0.46 or less. (Uganda, Zaire, Angola) . . . . dentata (p. 322)

6 Petiole in dorsal view relatively very broad, the node about as broad as long, DPI roo. (Cameroun, Zaire).

- Petiole in dorsal view relatively narrower, the node distinctly longer than broad, DPI $<85$

7 Eyes larger, ocular diameter $>0 \cdot 30$. Full adult colour black. Petiole in dorsal view with a median impression in the posterior margin. (W. \& C. Africa) minor (p. 324)

- Eyes smaller, ocular diameter<0.3o. Full adult colour deep brown or red-brown. Petiole in dorsal view usually without a median impression in the posterior margin. (Gabon, Equatorial Guinea, Zaire).

8 Head very coarsely sculptured dorsally with large pits or foveolae whose diameters are greater than the distances separating them or which are adjacent. Mesonotum and propodeum with a polished, virtually unsculptured median longitudinal strip. (Liberia, Ivory Coast, Ghana)

- Head punctate dorsally, the punctures small and separated by distances greater than their diameters; punctures never adjacent. Mesonotum and propodeum without a polished, virtually unsculptured median longitudinal strip

9 Mandibles edentate (Text-fig. I). Node of petiole relatively long, low and narrow, LPI $<90$, DPI $<70$. (Nigeria) . . . . . . . macgeei (p. 330)

- Mandibles at least with a strongly developed basal tooth and usually also with a second, smaller tooth in the apical half (Text-fig. 3). Node of petiole relatively short, high and broad, LPI $>$ IOo, DPI $>75$

Head and alitrunk in profile with numerous short, erect or suberect hairs projecting from the dorsum. (Principe Is.) . 
- Head and alitrunk in profile without hairs projecting from the dorsum _ . $\quad$ II

I I Ventral surfaces of head without striation between the punctures..$\quad$.

- Ventral surfaces of head with striation between the punctures, at least anteroventrally

12 Propodeal declivity armed near the base with a pair of stout triangular teeth, dorsal to which the laminae are not developed. Larger species, HL $>_{3} \cdot 0$. Full adult colour black or black-brown. (Tanzania) . . . . . . laevior (p. 329)

- Propodeal declivity not armed with teeth, the laminae running almost the length of the declivity. Smaller species, $\mathrm{HL}<2 \cdot 5$. Full adult colour red or orange-brown. (Ivory Coast, Kenya, Malawi, Rhodesia)

subterranea (p.333)

I3 Leading (anterior) margin of antennal scapes with a row of freely projecting, erect, short hairs. (Kenya, Tanzania, South Africa) . . . . . strigosa (p. 332)

- Leading (anterior) margin of antennal scapes without freely projecting short, erect hairs

I 4 Funicular segments $3-5$ at least as long as broad, usually longer than broad. Larger species, $\mathrm{HL}>3 \cdot$ o. (S. \& E. Africa, Angola, Zaire)

- Funicular segments 3-5 broader than long. Smaller species, HL $<_{3} \cdot{ }^{\circ}$. (Rhodesia, South Africa)

conjugata (p. 326)

\section{PROVISIONAL KEY TO KNOWN FEMALES}

Note: in the majority of species very few females are represented in collections; the key below should therefore be used with some caution.

I Alate species. If wings lost then the flight sclerites are fully developed. Ventral surfaces of head with the spaces between punctures smooth and shining . .

- Ergatoid species. Wings absent, never developed; flight sclerites never developed; sutures of dorsal alitrunk usually reduced or absent. Ventral surfaces of head with the spaces between punctures striate.

2 First gastral tergite with an anteriorly located transverse groove or impression.

- First gastral tergite without an anteriorly located transverse groove or impression

3 Larger, more thickset species, $\mathrm{HL}>3.60$, pronotal width at maximum $>2 \cdot 50$.

- Smaller, more slender species, $\mathrm{HL}<3.50$, pronotal width at maximum $<2 \cdot 40$. (Cameroun, Zaire)

.latinodis (p. 324)

4 Full adult colour deep red-brown. Petiole relatively longer and narrower, PL $\mathrm{I} \cdot 6 \mathrm{o}$, DPI $<8$ o. Smaller species, $\mathrm{HL}<3 \cdot 70$. (Gabon, Equatorial Guinea, Zaire)

gabonensis (p.323)

- Full adult colour black. Petiole relatively shorter and broader, PL $<\mathrm{r} \cdot 55$, DPI $>80$. Larger species, HL $>3 \cdot 70$. (W. \& C. Africa)

minor (p.325)

5 Dorsal surfaces of head and alitrunk with numerous short, erect or suberect hairs. (Principe Is.)

gestroi (p. 329)

- Dorsal surfaces of head and alitrunk without erect or suberect hairs

6 Dorsum of head with large punctures or foveolae whose diameters are greater than the distances separating them or which are adjacent. Head black. Smaller species, HL < I·55. (Liberia, Ivory Coast, Ghana) .

cryptica (p. 328)

- Dorsum of head with small, fine, scattered punctures whose diameters are smaller than the distances separating them and which are never adjacent. Head red or red-brown. Larger species, $\mathrm{HL}>_{\mathrm{I}} \cdot 75$

7 Antennal scapes when laid back failing to reach the level of the lateral ocelli. Smaller species with relatively low petiole, $\mathrm{HL}<2 \cdot 0, \mathrm{LPI}<$ I Io. (Uganda, Zaire)

ugandensis (p. 334)

- Antennal scapes when laid back surpassing the level of the lateral ocelli. Larger species with relatively high petiole, $\mathrm{HL}>2 \cdot 0, \mathrm{LPI}>\mathrm{II}_{5}$. (Ivory Coast, Kenya, Malawi, Rhodesia) 
8 First gastral tergite with an anteriorly located transverse groove or impression.

Petiole relatively long and narrow, DPI $<85$. $\quad . \quad$. . . . . . . .

- First gastral tergite without an anteriorly located transverse groove or impression.

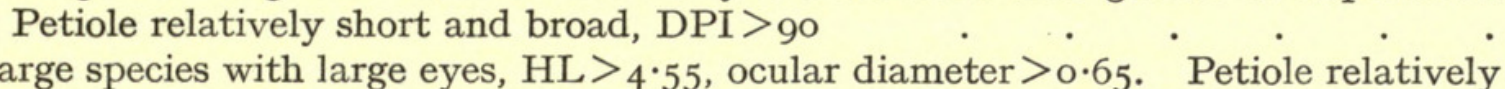

9 Large species with large eyes, $\mathrm{HL}>4 \cdot 55$, ocular diameter $>0 \cdot 65$. Petiole relatively

- Smaller species with small eyes, $\mathrm{HL}<4.55$, ocular diameter $<0.55$. Petiole relatively broad dorsally, DPI $>7$. (Uganda, Zaire, Angola) . dentata (p. 322)

Io Large species with relatively long mandibles, $\mathrm{HL}>>_{4} \cdot 0, \mathrm{SL}>2 \cdot 90, \mathrm{MI}>8_{3}$. (S. \& E. Africa, Angola, Zaire) . . . . . . . mandibularis (p. 33I)

- Smaller species with relatively shorter mandibles, $\mathrm{HL}<4 \cdot \mathrm{O}, \mathrm{SL}<2 \cdot 8 \mathrm{o}, \mathrm{MI}<8_{3}$.

(S. Africa, Rhodesia) . . . . . . . . . . conjugata (p. 326)

THE HASTIFER-GROUP

Basal tooth of mandible absent; apical portion of mandible swollen. Propodeal laminae forming a continuous rim around the sides and dorsum of the declivity. First gastral tergite without an anteriorly situated transverse groove or impression. Head considerably longer than broad, CI $<8$ o. Petiole in profile long and low, noticeably longer than high, LPI<Ioo. Eyes minute or absent. Sculpturation of head of coarse punctures or foveolae, the diameters of the individual punctures greater than the distances separating them, or the punctures virtually adjacent.

The two species known in this small group have been found only in the forest zone of eastern Ghana. Both are elongate, relatively slender forms with a red or red-brown colour and with the eyes very small or lacking. In view of these characters a completely subterranean lifeway is postulated for the species.

\section{Plectroctena anops sp. n.}

\section{(Text-figs 4, 7)}

Diagnosis of worker. Eyes absent. Mandibles without a differentiated basal tooth, the apex swollen. Propodeal laminae strongly developed, continuous around the dorsum and sides of the declivity. First gastral tergite without a transverse groove anteriorly. Dorsum of head with large pits or foveolae whose diameter is greater than the distances separating them.

Further Description. Holotype worker. TL $7 \cdot 4, \mathrm{HL}$ I $68, \mathrm{HW}$ I 32 , CI $78, \mathrm{ML}$ I·20, MI 7I, SL 0.98, PH 0.72, PL 0.80, LPI 90, DPW 0.56, DPI 70.

Mandibles without a basal tooth. In dorsal view the apical halves of the mandibles swollen, broader than the basal halves; tapering towards the apex. On the inner margin of each mandibular blade, at the point where the mandibles increase in width, is a small, blunt, dentiform prominence. Eyes absent. Posterior margin of head almost straight, only very shallowly concave in full face view. General outline of head as shown in Text-fig. 4. Funicular segments 2-Io distinctly broader than long. Propodeal laminae strongly developed, broad, translucent, meeting dorsally so that the declivity is encircled on both sides and narrowly above. Femoral grooves of middle and hind legs reduced but still visible. Petiole in profile blocky and massive, slightly longer than high; in dorsal view long and narrow, gradually increasing in width from front to back. First gastral tergite rounded anteriorly in dorsal view, its width increasing posteriorly. Second tergite with sides nearly parallel, only very weakly convex and somewhat convergent posteriorly.

Dorsum, sides and ventrolateral surfaces of head densely covered with large punctures or 
foveolae which are contiguous or nearly so, their diameters noticeably greater than the distances separating them. Dorsal alitrunk similarly but more shallowly sculptured, the pronotal disc with the punctures more closely approximated than on the sides and similarly with the remainder of the alitrunk. Sides of alitrunk with a few weak striae between punctures. Propodeal declivity smooth and highly polished. Petiole sculptured as alitrunk. First and second gastral tergites and sternites densely covered with punctures or foveolae.

Dorsal surfaces of head, alitrunk and gaster with a diffuse, decumbent pubescence which is directed toward the mid line. Erect hairs present only on mouthparts, legs and apex of gaster.

Full adult colour red-brown.

Holotype worker, GhanA: Tafo, 8.ix.I966, ant ecology sample 249c (D. Leston) (BMNH).

This small species is most closely related to hastifer, from which it may be separated by its size, lack of eyes and absence of erect hairs from the dorsal surfaces of the head and body.

\section{Plectroctena hastifer (Santschi) comb. n.}

(Text-figs 2,6)

Cacopone hastifer Santschi, I914b :325, fig. II. Holotype worker, GHANA: Aburi (F. Silvestri) (IE, Naples).

Diagnosis of worker. Mandibles without a basal tooth, their apices swollen. Dorsal surfaces of head, alitrunk, petiole and first two gastral segments with numerous erect hairs. Anterior and dorsal surfaces of petiole confluent, meeting through a smooth curve, not separated by an angle. Dorsum of head coarsely punctate, the diameter of the punctures greater than the distance separating them. First gastral tergite without an anterior transverse groove. Propodeal laminae meeting dorsally, continuous around the declivity.

Further Description. Worker. TL I0.9, HL $2 \cdot 40, \mathrm{HW}$ I 84 , CI 77, ML I.68, MI 70, $\mathrm{SL} \mathrm{I} \cdot 48, \mathrm{PH} 0 \cdot 84, \mathrm{PL}$ I 24 , LPI 68, DPW o.64, DPI 52.

Mandibles edentate, the distal half swollen, considerably broader than the proximal, tapering apically. Head considerably longer than broad, the occipital margin virtually straight, only extremely shallowly concave. Eyes present, depigmented, very small, ocular diameter O.IO-O.I2. Funicular segments $3-9$ noticeably broader than long. Dorsal groove or thin strip absent from middle, present on hind femora. Propodeal laminae contiguous dorsally, translucent, forming a continuous lamella around the declivity. Node of petiole in profile long and low, the anterior and dorsal surfaces confluent through a continuous shallow curve, not separated by an angle. In dorsal view the first gastral tergite rounded anteriorly.

Sculpture everywhere of large but quite shallow punctures or foveolae whose diameters are equal to or greater than the distances separating them. The spaces between the punctures are smooth and shining except on the sides of the alitrunk and petiole, where striae are present.

Dorsal surfaces of head, alitrunk, petiole and first and second gastral tergites with numerous short, erect hairs. Full adult colouration a deep red.

Most closely related to anops but separable from it by the smaller size of that species and its lack of eyes or erect hairs.

MATERIAL EXAMINED.

Ghana: Tafo (D. Leston). 


\section{THE MINOR-GROUP}

Basal tooth of mandible present and each blade also with a second, more apically placed tooth which is usually very small, sometimes no more than a faint prominence. Apical portion of mandible not swollen. Propodeal laminae restricted to the sides of the declivity, often very weakly developed. First gastral tergite with an anteriorly placed transverse groove or impression which is often strongly developed but which may be reduced and only clearly visible medially. Head relatively broad, the measured range of CI 89-97. Petiole in profile as high as long or higher than long, LPI Ioo or more. Eyes present, usually well developed but small in some species. Dorsum of head sculptured with fine, widely spaced punctures.

This group contains five species, linked by the characters noted above. Within the group the species separate into two complexes, one based upon minor itself and including also gabonensis and latinoda, in which the females are alate and the ventral surfaces of the head are smooth between the punctures, and the second based upon cristata and dentata in which the females are ergatoid and the ventral surfaces of the head are striate between the punctures.

The distribution of the species of the minor-group is mostly restricted to the rain forests of West and Central Africa, but cristata and dentata have been found in the forests of Kenya and Uganda respectively. Eidmann (I944) reported the presence of gabonensis upon the island of Fernando Po in the Gulf of Guinea, the only member of this group to be found off the mainland.

For nesting sites the members of the group appear to prefer the wood of very rotten or collapsed logs and foraging is carried out under the bark and in the wood of such logs as well as under the bark of more recently dead wood.

\section{Plectroctena cristata Emery}

Plectroctena cristata Emery, I899:470. Syntype workers, Cameroun (Conradt) (probably in MCSN, Genoa).

Plectroctena cristata var. semileavis Santschi, I924: I63. Holotype worker, ZAIRE: Luebo, Kamaiembi 22.ix.I92I (H. Schouteden) (MRAC, Tervuren) [examined]. [Variant spelling as semilaeve op. cit.: I73.] Syn. n.

Diagnosis of WORker. Very large species, $\mathrm{HL}>_{4} \cdot{ }^{\circ}$. First gastral tergite with a strongly marked transverse groove anteriorly. Dorsum of head often with a shallow, broad, transverse impression posteriorly which is interrupted medially. Funicular segments 3-5 longer than broad. Sides of head behind eyes with the spaces between punctures usually finely striate. Ocular diameter $0 \cdot 48-0 \cdot 62$.

FURTHER DESCRIPTION. Worker TL $21 \cdot 6-23 \cdot 2$, HL $4 \cdot 40-4 \cdot 60$, HW 4.12-4 32, CI 93-94,

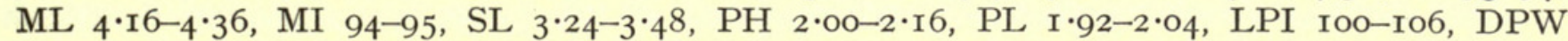
$\mathbf{I} \cdot 32-\mathrm{I} \cdot 36$, DPI $67-69$ (5 measured).

Sides of head expanded and convex in front of the eyes. Palp formula 3, 4. Dorsal surface of head posteriorly usually with a shallow or very shallow, broad transverse impression which is interrupted medially. In some specimens this character is faint or absent. Funicular segments 3-9 at least as long as broad, usually longer than broad. Pronotal dorsum usually without, very rarely with a median longitudinal impression posteriorly. When present this character is extremely faint. Outline shape of propodeal laminae in profile variable but usually with a rounded prominence about half way down the declivity which in some may be bluntly dentiform. Anterior transverse groove of first gastral tergite strongly developed, clearly visible in profile and running almost or quite the anterior width in dorsal view.

Dorsum of head with scattered fine punctures, the interspaces shining mediodorsally and 
usually striate laterodorsally, but in some individuals striae are present over the entire surface. Sides of head usually, and ventral surface always, striate between the punctures. Dorsal alitrunk and first two gastral tergites usually with the interpunctural spaces smooth and shiny, more rarely with the spaces shagreened or finely striate. Lateral portions of the first tergite often striate between punctures, as are the lateral portions of the first sternite. Full adult colour black.

Female. TL $24 \cdot 2, \mathrm{HL}_{4} \cdot 64$, $\mathrm{HW}_{4} \cdot 52, \mathrm{CI} 99, \mathrm{ML} 4 \cdot 40, \mathrm{MI} 95$, SL $3 \cdot 40, \mathrm{PH} 2 \cdot \mathrm{I} 6$, PL $2 \cdot 04$, LPI 106, DPW I·40, DPI 68.

Ergatoid. Slightly larger than the largest worker measured; ocular diameter $0 \cdot 72$. Ocelli present, the median more strongly developed than the laterals. Metanotal groove present. Mesoscutellum delineated upon the dorsal alitrunk. Sculpturation of head fainter and less well defined than in worker. Otherwise as worker.

This very large species is most closely related to dentata but is separable by the characters given in the keys.

\section{MATERIAL EXAMINED.}

Cameroun: no loc. (ex coll. Santschi); Ntsama (B. de Miré). ZaIre: Ubangi, Binga (H. J. Bredo); Niapu (H. O. Lang). Kenya: Kibale Forest (A. Loveridge).

\section{Plectroctena dentata Santschi}

Plectroctena minor var. dentata Santschi, I9I2 : I50. Syntype workers, Angola: Benguela, Cucala (J. Cruchet) (NM, Basle; MRAC, Tervuren) [examined].

Plectroctena dentata Santschi; Santschi, I924 : I64 fig. Ic. [Raised to species.]

Plectroctena emeryi Santschi, I924: I64. Holotype female (ergatoid; not worker), Congo (J. de Gaule) (NM, Basle) [examined]. Syn. n.

DiAgNosis of WORKER. First gastral tergite with a weakly developed transverse groove anteriorly. Funicular segments $3-5$ about as broad as long. Ocular diameter $0 \cdot 42-0 \cdot 46$. Ventrolateral and ventral surfaces of head with striae between the punctures.

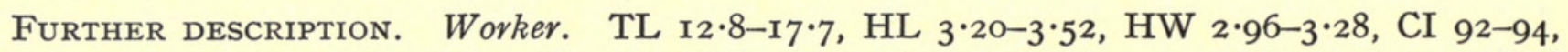
ML $2 \cdot 34-3 \cdot 00$, MI $75-85$, SL $2 \cdot 08-2 \cdot 36$, PH I·36-1 52 , PL I·28-1 48 , LPI 103-106, DPW $0 \cdot 96-\mathrm{I} \cdot 08$, DPI $7 \mathrm{I}-75$ (5 measured).

Sides of head in front of eye very slightly or not expanded, forming a more or less continuous line with the remainder of the sides. Eyes of moderate size, ocular diameter $0 \cdot 42-0 \cdot 46$. Funicular segments $3-5$ about as broad as long but distal to this becoming noticeably broader, segments 7-9 obviously broader than long. Pronotal dorsum without a median longitudinal impression (but as this character is commonly developed in species of this group specimens will probably be found in which it does occur). Propodeal laminae in profile usually starting a short distance down the declivity and expanded at this point into a bluntly dentiform prominence, variable in shape and size even in members of the same nest-series. Transverse impression of first gastral tergite usually faint and poorly developed, only visible in the middle of the tergite, often scarcely discernible in profile.

Dorsum of head with fine, scattered punctures, the interspaces smooth and shining. Below the eye (and more rarely also behind it) and the ventral surfaces of the head with fine striae between the punctures. Dorsal alitrunk and first and second gastral segments smooth and shining between the punctures. Occasionally a few faint striae may be present on the propodeal dorsum.

Female. TL $22 \cdot 6-23 \cdot 2$, HL $4 \cdot 20-4 \cdot 28$, HW $4 \cdot 08-4 \cdot$ I2, CI 95-98, ML 3.76-3.90, MI 88-93,

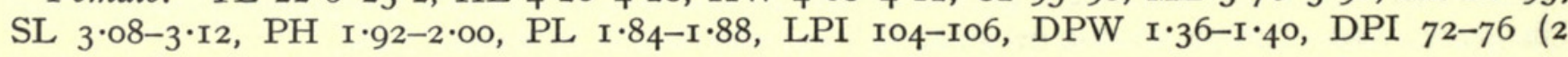
measured). 
Ergatoid. Ocular diameter $0 \cdot 48-0.50$. Ocelli present or head with a pair of distinct pits marking the vestiges of the lateral ocelli. Metanotal groove present but poorly defined. Propodeal laminae not dentiform but with an angular portion at about the midlength. Groove on the first gastral tergite more strongly developed than in the worker; the striate sculpturation of the ventral surface of the head less strongly developed. Otherwise as worker.

MATERIAL EXAMINED.

Uganda: Busia (E. S. Ross \& R. E. Leech). ZaIre: Kisenje (?).

\section{Plectroctena gabonensis Santschi}

Plectroctena gabonensis Santschi, I9I9a:336. Syntype workers, GABON: Libreville, r.xii.I897 (Chalot), and GABon: Samkita I9I4 (F. Faure) (NM, Basle) [examined].

Note: Santschi described this species twice as new; first as above and later the same year as subterranea st. gabonensis Santschi, I9I9b:90. Both descriptions were based upon the same specimens.

DiAgNosis OF WORKER. As minor but first gastral tergite with the transverse groove very weak, usually only plainly visible in the middle of the sclerite. Petiole in dorsal view without a median impression in the posterior margin. Eyes small, ocular diameter $0 \cdot 22-0 \cdot 26$.

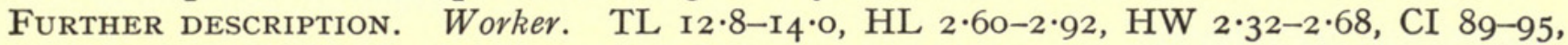

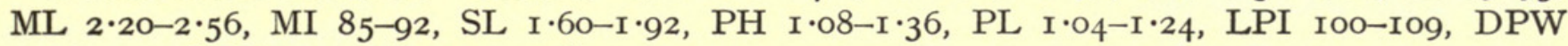
$0 \cdot 76-0 \cdot 92$, DPI 73-75 (8 measured).

As minor but averaging slightly smaller than that species. The eyes are noticeably smaller, with a maximum ocular diameter of 0.26 (compared to a minimum ocular diameter of 0.32 in minor). Propodeal laminae very poorly developed, scarcely more than a pair of weak ridges, not projecting as bluntly dentiform prominences. In dorsal view the posterior margin of the node usually lacks a median impression. The transverse groove on the first gastral tergite is very weak indeed; in some specimens only a faint impression in the middle of the sclerite is visible and this impression is only poorly defined in profile. Full adult colour is deep red-brown, as opposed to black or black-brown in minor.

Female. A fully alate queen in $\mathrm{MCZ}$, Cambridge is suspected as the female of this species. It resembles the worker but is larger, with fully developed flight sclerites and ocelli. Its dimensions

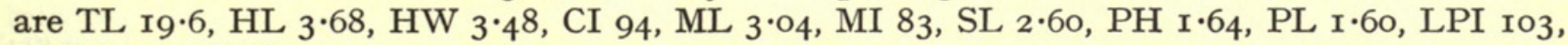
DPW I 20 , DPI 75 .

\section{MATERIAL EXAMINED.}

Gabon: no loc. (ex coll. F. Smith). Equatorial Guinea: Fernando Po (Conradt). ZaIre: Tshela (E.S. Ross \& R. E. Leech); Eala (J. Ghesquière); Uele, Buta (R. F. Hutsebaut); Equateur, Bokuma (R. P. Hulstaert).

\section{Plectroctena latinodis Santschi}

Plectroctena latinodis Santschi, I924: I65, fig. 2a. Syntype worker, female, ZAIRE: Congo da Lemba (R. Mayné) (MRAC, Tervuren, NM, Basle) [examined].

DiAGNOSIS OF WORKER. As minor but the petiole relatively higher, LPI I I 5, and considerably broader, DPI roo. Transverse groove on first gastral tergite developed only in the middle of the sclerite and situated at the extreme anterior margin. 
Further DESCRIPTION. Worker. TL 15 $_{5} \cdot 6$, HL 3.16, HW 2.92, CI 92, ML 2.72, MI 86, $\mathrm{SL} 2 \cdot 08, \mathrm{PH}$ I $\cdot 20, \mathrm{PL} \mathrm{I}^{\circ} \cdot 04, \mathrm{LPI} \mathrm{II}_{5}$, DPW I $\cdot 04$, DPI гоo.

As minor, but latinodis is slightly smaller and its ocular diameter is at the bottom of the size range seen in minor workers $(0 \cdot 32)$. Propodeal laminae very poorly developed, scarcely more than a pair of weakly raised ridges. Transverse groove of first gastral tergite strongly developed in the median portion of the sclerite only, and is very close to the anterior border of the tergite. The shape of the petiole node is immediately diagnostic of the species. In profile it is high and narrow, lacking the impression or discontinuity of outline in the anterodorsal margin which is seen in minor and usually also in other related species. In dorsal view the node is blocky and broad, with a DPI in the syntype worker of Ioo, compared to the maximum recorded DPI of 76 in workers of other species of the group.

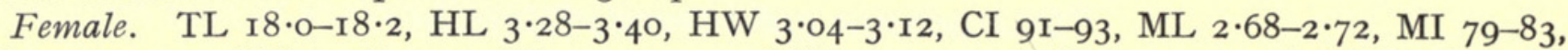

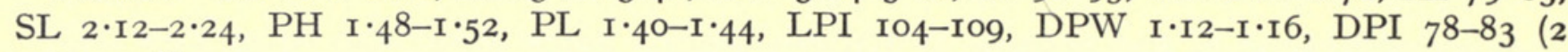
measured).

Alate, the alitrunk with developed flight sclerites. Ocelli present, the median and laterals of approximately equal size. Ocular diameter $0.56-0.58$. Petiole not nearly so high and broad as in worker. Otherwise as worker.

The female approximates much more closely to minor and gabonensis than the worker but is smaller and more slenderly built. The maximum width of the pronotum in specimens measured has a range $2 \cdot 20-2 \cdot 32$ as opposed to a minimum pronotal width of $2 \cdot 64$ in the other two species.

\title{
MATERIAL EXAMINED.
}

CAmeroun: Mundame (Conradt).

\section{Plectroctena minor Emery}

\author{
(Text-figs 3, 9)
}

Plectroctena minor Emery, I891 : 556, pl. I5, figs I, 2. Holotype female, Ivory CoAst: Assinie, vii-viii. 1886 (Ch. Alluaud) (probably in MCSN, Genoa).

Plectroctena minor var. perusta Santschi, I924: I68, fig. 2b. Syntype workers, Cameroun: Barumbistation (Preuss) (NM, Basle) [examined]. Syn. n.

Plectroctena minor var. liberiana Santschi, I924: 169, fig. 2c. Holotype worker, Liberia (NM, Basle) [examined]. Syn. n.

Plectroctena minor var. insularis Santschi, I924 : I69, fig. 3a. Holotype worker, EQUATORIAL Guinea: Fernando Po (Convadt) (probably in MCSN, Genoa). Syn. n.

DiAgnosis OF WORKer. First gastral tergite with a strongly marked transverse groove anteriorly. Sides of head behind and below eyes without striae between the punctures. Petiole in dorsal view usually with a weak median impression in the posterior margin. Ocular diameter $0 \cdot 32-0 \cdot 36$. Funicular segments $3-5$ broader than long. LPI $<$ I I $5_{5}$, DPI $<90$.

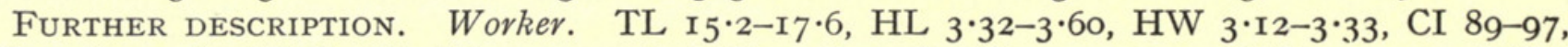
ML $2 \cdot 84-3 \cdot 28$, MI $85-88$, SL $2 \cdot 32-2 \cdot 48$, PH I·36-I 48 , PL I $24-1 \cdot 40$, LPI IOo-II2, DPW 0.92-I.00, DPI 69-76 (Io measured).

Sides of head in front of eyes somewhat expanded, the outer margins convex. Palp formula 3, 4. Eyes of moderate size, measured range of ocular diameter $0 \cdot 32-0 \cdot 36$. Funicular segments 3-Io noticeably broader than long. Pronotum with or without a median longitudinal impression. In some populations this character is distinct, in others faint, but very often absent. Propodeal laminae usually only weakly developed, most commonly with a low, dentiform prominence or angle at about one-third the distance down the declivity. Node of petiole in profile often with 
a slight impression or discontinuity of outline in the anterodorsal surface; and in dorsal view with a slight impression in the middle of the posterior margin. Transverse groove on first gastral tergite strongly developed, clearly visible both in dorsal view and in profile.

Dorsum, sides and ventral surfaces of head with fine scattered punctures, the spaces between which are smooth and shining, not striate. Dorsum of alitrunk and first and second gastral tergites and sternites with similar sculpture. Full adult colour black or black-brown.

Female. TL 19.2-2I.4, HL 3.72-3.84, HW 3.28-3.60, CI 88-94, ML 3.12-3.20, MI 82-83, SL $2 \cdot 48-2 \cdot 64$, PH I·64-I·76, PL I·46-I·48, LPI IIO-II9, DPW I·20-I·24, DPI 8 I-84 3 measured).

Alate, flight sclerites developed. Eyes larger, ocular diameter $0 \cdot 62-0 \cdot 68$. Ocelli present. Otherwise as worker.

This species is not uncommon in eastern Ghana and western Nigeria and is usually found in quite dense forest or woodland in which there is an abundance of fallen and rotting wood. The majority of collections of this species made by the author were in or under rotten logs, a preference apparently being shown for logs which still retained some bark in a loose condition. Nests on the other hand appear primarily to be built in extremely rotten or collapsed logs and on one occasion a single dealate female was found in a portion of fallen and rotting carton nest of a Crematogaster species. Fragments of millepedes were found amongst the detritus of a nest excavated at Gambari, Nigeria, indicating that diplopods make up at least a part of the diet of minor.

MATERIAL EXAMined.

Sierra Leone: no loc. (ex coll. F. Smith). Ghana: Tafo (B. Bolton). Nigeria: Gambari (B. Bolton). ZAIRE: Tonolu (H. Schouteden): Stanleyville (H. Kohl); Pweto (E.S. Ross \& R. E. Leech).

\section{THE MANDIBULARIS-GROUP}

Basal tooth of mandible usually strongly developed (absent in macgeei), the apical portion of the mandible not swollen. Propodeal laminae restricted to sides of declivity, often weakly developed. First gastral tergite without a transverse groove or impression anteriorly. Head relatively broad, measured range of CI 86-95. Petiole in profile as high as or higher than long (LPI roo or more) except in macgeei (LPI 89). Eyes present, usually well developed but small in some species. Sculpture variable amongst members of the group.

This group of nine species separates into two complexes and a solitary, rather aberrant species which in many respects differs from all the others included. The first complex includes mandibularis, conjugata, strigosa, laevior and gestroi which are large, black species, and the second includes subterranea, ugandensis and cryptica which are smaller, red or red-brown species.

The anomalous macgeei stands out sharply from this assemblage as it is small (about the same size as the larger subterranea specimens) but black in colour, and possesses edentate mandibular blades and a relatively long, low and narrow petiole node.

The most widely distributed species of the group, and also of the genus as a whole, is mandibularis, which is known throughout southern and eastern Africa (reaching as far north as Ethiopia) and which also occurs in parts of Zaire and Angola. 
Compared with this the known ranges of the other species are small indeed. Conjugata is known from South Africa and Rhodesia, laevior from Tanzania, ugandensis from Uganda and Zaire, and cryptica from a number of West African countries. Of the remaining species, macgeei and gestroi have been recorded by their type-localities only, namely Nigeria and Principe Island.

The known range of subterranea, from Malawi, Rhodesia and the savannah of Ivory Coast, suggests that this species is present throughout much of the savannah regions of Africa, but as its habits are probably wholly subterranean it will be a long time before its true distribution can be ascertained.

Nesting sites of the representatives of this group are terrestrial in most species, the nests being built in the earth either directly or under a stone or log.

\section{Plectroctena conjugata Santschi}

Plectroctena minor st. conjugata Santschi, I9I4a: 8. Syntype workers, female, South Africa: Natal, Stamford Hill, Charlestown 3o.iv.I9o5, and Zululand (I. Trägårdh) (MCZ, Cambridge; MRAC, Tervuren; NM, Basle) [examined].

Plectroctena conjugata Santschi; Santschi, 1924 : r66. [Raised to species.]

DiAgNosis OF WORKER. As mandibularis but smaller, $\mathrm{HL}<3 \cdot 00$; ocular diameter $0 \cdot 32-0 \cdot 38$. Funicular segments 3-5 broader than long.

FURTHER DESCRIPTION. Worker. TL II $\cdot 8-\mathrm{I}_{4} \cdot 6$, HL $2 \cdot 68-2 \cdot 96$, HW $2 \cdot 48-2 \cdot 72$, CI $89-92$,

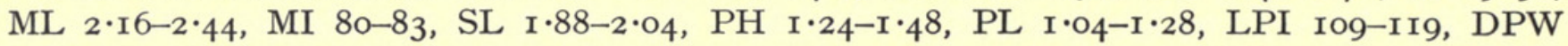
0.96-I.I2, DPI 80-92 (Io measured).

As mandibularis but averaging smaller in size and with somewhat smaller eyes. Funicular segments 3-5 usually noticeably broader than long but in some specimens only slightly so. Palp formula 3, 4. Striae on the ventral surfaces of the head less strongly developed than is usual in mandibularis, commonly restricted to the anterior half or one-third of the ventrolateral surfaces. A median longitudinal groove is often present on the pronotum but specimens in which it is weakly developed or absent are frequently found. Sculpturation in the species is subject to the same variation as is noted in mandibularis but forms with either the dorsal head or dorsal gaster striate are not known, nor are individuals showing a predominantly striate sculpture everywhere.

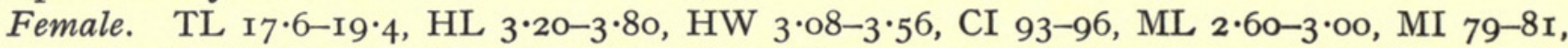

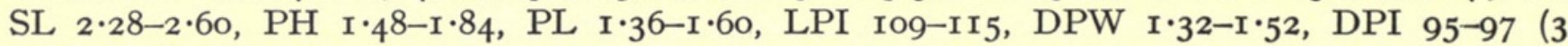
measured).

Ergatoid; sutures of alitrunk reduced, developed flight sclerites lacking. Larger and more stockily built than the worker, with larger eyes, ocular diameter $0 \cdot 48-0 \cdot 60$. Ocelli absent in specimens examined but ocellar vestiges in the form of a pair of strong pits are present on the head at the site of the lateral ocelli. Petiole relatively shorter and broader than in the worker. Otherwise as worker.

On characters shown by the worker alone, conjugata is not easily separated from mandibularis and I am not convinced that the two actually represent distinct species. Santschi (I924) separated them in his key on the character of relative length and thickness of the funicular segments, on the grounds that in conjugata these segments were broader than long whilst in mandibularis they were longer than broad. In both the collections of $\mathrm{BMNH}$ and $\mathrm{MCZ}$, Boston, however, are specimens of mandibularis in which the funicular segments are only just as long as 
broad and it is not difficult to envisage all the known forms as being expressions of the same species.

Turning to the female one apparently has a number of mensurable characters which separate the two quite well (see key to females) but as so few specimens are available such differences may prove to be illusory when the queen castes are better known.

The male of conjugata is known (Santschi, I924) and shows a striking difference from that of mandibularis in that the gaster of the former is black whilst that of the latter is red or orange-brown. Numerous collections of the male of mandibularis have been made and all have the contrasting gastral colour. Unfortunately only three collections of conjugata male are known and so the usefulness of this character cannot be estimated at present.

Obviously then, the question of whether conjugata is a distinct species cannot be settled satisfactorily at present, and a decision must await the amassing of more specimens of all three castes.

Dr W. L. Brown Jr informs me that the food of conjugata in South Africa consists of millepedes, and that their rubbish heaps contain many cleaned out ring-segments of these arthropods.

\section{MATERIAL EXAMINED.}

Rhodesia: Umtali, Cecil Kop (W. L. Brown); Vumba Mts. (G. Arnold). South Africa: Grahamstown, Howisons Poort (W. L. Brown); W. Grahamstown (W. L. Brown); Grahamstown (F. Jacot-Guillarmod); Grahamstown (J. Hewitt); Port Elizabeth (H. Brauns); Gomodimo (Vernay-Lang); Natal (ex coll. Santschi); Natal, Isipingo (H. B. Marley); Natal, Sydenham (H. B. Marley).

\section{Plectroctena cryptica sp. n.}

$$
\text { (Text-fig. 5) }
$$

DiAgnosis of worker. Head coarsely punctate, the diameter of the punctures greater than the distance separating them. Dorsal alitrunk with similar but more widely spaced and fainter punctures, the mesonotum and propodeum with a narrow, polished, virtually unsculptured median strip. First gastral tergite without a transverse anterior groove. Sparse, decumbent pubescence on head pointing towards the midline.

FURTHER DESCRIPTION. Holotype worker. TL 6.9, HL I·40, HW I·20, CI 86, ML I·oo, MI 7I, SL 0.84, PH 0.72, PL 0.64, LPI I I2, DPW o•60, DPI 94.

Mandibles with dentition very reduced. Basal tooth reduced to an angle, best seen in dorsolateral view, the remainder of the mandible edentate. Eyes minute, ocular diameter about o.08. Occipital margin of head virtually straight in full-face view, only extremely weakly concave. Funicular segments 2-9 distinctly broader than long. Propodeal laminae strongly developed, extending the length of the declivity, not produced into dentiform prominences. Petiole in profile blocky, higher than long, the dorsal surface shallowly convex. Anterior face of petiole in profile sloping, virtually straight, the posterior face shallowly convex. In dorsal view the petiole is narrowest in front and strongly broadened behind, the posterior border shallowly concave. First gastral tergite without a transverse groove anteriorly.

Dorsum, sides and ventral surfaces of head coarsely and closely punctured, the diameter of the punctures as great as or greater than the distances separating them. Dorsum of alitrunk 
with similar but more widely spaced and shallower punctures and with an unsculptured, shining median strip running the length of the mesonotum and propodeum. Rest of body punctate, the spaces between punctures smooth and shining except on the sides of the alitrunk and petiole where striae are present. Striae strongest on metapleuron and sides of propodeum, where the punctures are almost effaced.

Erect hairs present only on mouthparts and gastral apex but a scattered decumbent pubescence is present on head, alitrunk and gaster, pointing towards the mid line on the head. Full adult colour deep red-brown.

Paratypes as holotype but smaller, size range TL $5 \cdot 7-6 \cdot \mathrm{I}, \mathrm{HL} \mathbf{I} \cdot \mathbf{I} 4-\mathrm{I} \cdot 24, \mathrm{HW} 0 \cdot 96-\mathrm{I} \cdot 04$, CI 84-85, ML 0.74-0.86, MI 65-69, SL 0.64-0.68, PH o.62-0.68, PL $0 \cdot 54-0 \cdot 58$, LPI II $5-$ I I 7 , DPW 0.48-0.56, DPI 88-96 (3 measured).

The mandibles show the development of a minute, weak, angular tooth in the apical half of their length, absent from the holotype, and also have a few weak punctures at the posterior end of the polished median strip of cuticle on the propodeum. Ocular diameter shows a range of $0 \cdot 06-0 \cdot 08$.

Holotype worker, Ghana: Tafo, 2.i.I969, on mud below dam (B. Bolton) (BMNH). Paratypes. 3 workers, Ivory CoAst: Lamto (Toumodi), Ir.iv.I968 (sample AA 279 N2), 20.vi.I968 (sample AA 334 N4), and 2I.ii.I969 (J. Lévieux) (BMNH; MCZ, Cambridge).

The holotype worker was found walking on a patch of muddy soil on the bank of the overflow stream of the dam at Tafo. The embankment of the stream immediately above the spot was in process of being excavated and it is assumed that this ant originated in the soil of the embankment.

This small species, the smallest known in the genus at present, is easily recognisable by its size and by the characters given in the diagnosis. The most closely related species appears to be subterranea as the form of the petiole node is similar in the two.

Putative female. TL $7 \cdot 8$, HL ז 46 , HW г 32 , CI 9o, ML ז 02 , MI 7 o, SL o 88 , PH o.76, PL 0.70, LPI I08, DPW o.64, DPI 9I.

Alate, flight sclerites fully developed. Eyes large for so small a species, ocular diameter o.32. Ocelli present. Occipital margin broadly concave. Propodeal laminae narrow, alitrunk without a polished, unsculptured median strip. Head black, the remainder of the body brown or brown-black, with areas of differing colour upon the alitrunk. Otherwise as worker.

I have tentatively associated this female from Monrovia, Liberia (in MCZ, Cambridge) with the workers of cryptica. The two are very similar and only the minor differences given above separate them. Most of these differences are due to caste, and perhaps the variation in colour and sculpturation can also be attributed to this cause.

\section{Plectroctena gestroi Menozzi}

Plectroctena gestroi Menozzi, I922 : 348, fig. I. Syntype workers, female, Principe Is.: Roca Infante Don Enrique, iii. I9oo (L.Fea) (IE, Bologna; MCZ, Cambridge) [examined]. (Syntype worker from $\mathrm{MCZ}$, Cambridge lacks head).

Diagnosis of worker. Dorsal surfaces of head, alitrunk, petiole and first gastral tergite with numerous short, erect or suberect hairs.

Further DESCRIPTION. Worker. TL I4.5, HL 3.00, HW 2.84, CI 94, ML 2.56, MI 85 , SL $2 \cdot 40$, PH I·36-I·48, PL I·24, LPI IIO-II9, DPW I•oo, DPI 80-8I (2 measured). 
Basal tooth of mandible strongly developed. Eyes small, ocular diameter 0.32. Funicular segments 3-6 broader than long. Resembling conjugata but differing from that species by the presence of numerous short, erect or suberect hairs on the dorsal and lateral surfaces of the head and body. The middle and hind femora of gestroi have a number of projecting hairs ventrally, most conspicuous basally, which contrast to the short, reclinate hairs seen in this position in conjugata. Punctures of the cephalic dorsum are coarser and somewhat more closely spaced than in conjugata and the ventral surface of the head lacks striation between the punctures.

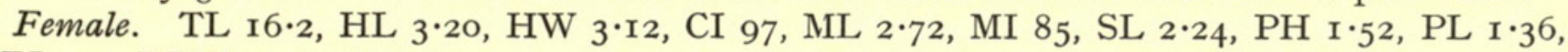
LPI II2, DPW I·I6, DPI 85.

As worker but alitrunk with full complement of flight sclerites. Ocelli present; ocular diameter 0.58 . Dorsum of head coarsely and irregularly punctate. Punctures of the ventral surfaces of the head with the interspaces smooth and shining. Gastral tergites finely and densely punctate, the sternites rather more coarsely so, with smooth, shining interspaces. Hairs of head, alitrunk and gaster relatively shorter and more reclinate than in worker. Sides of head in full-face view with numerous hairs projecting freely beyond the margins, directed anteriorly. Projecting hairs on the ventral surfaces of the femora longer and more strongly developed than in the worker.

This easily identifiable species is at present the only member of the genus recorded from Principe Is. As far as can be ascertained it is not yet known from the mainland, though I suspect that it will eventually be found in Central Africa.

\section{Plectroctena laevior Stitz stat. n.}

Plectroctena mandibularis st. laevior Stitz, in Santschi, I924: r63, fig. Id. Holotype worker, TANZANIA: Kiwugebiet (Kadt) (MNHU, Berlin) [examined].

Diagnosis of worker. Propodeal declivity armed with a pair of stout triangular teeth near the base. Median portion of declivity below level of teeth transversely convex. Ventral surfaces of head without striae. First gastral tergite without a transverse groove anteriorly.

Further DESCRIPTION. Worker. TL I8.3, HL 3.68, HW 3.44, CI 93, ML 3.28, MI 89 , SL $2 \cdot 56$, PH I 76 , PL I·56, LPI I 13 , DPW I $\cdot 36$, DPI 87.

Basal tooth of mandible strongly developed, the more distal merely a low, rounded swelling. Ocular diameter $0 \cdot 44$. Funicular segments 3-5 about as broad as long. Sides of head only weakly expanded in front of eye, the occipital margin strongly concave medially. Propodeal declivity armed near the base with a pair of broad, triangular teeth, situated above the strongly developed metapleural lobes. Dorsal to the teeth the propodeal laminae are not developed and only a weak margination separates the declivity from the sides. The basal portion of the declivity between the level of the spines and the metapleural lobes is transversely convex and swollen medially and this swollen portion is flanked by a pair of large, deep pits which are almost circular. In other related species these pits are reduced or absent or are situated in each side of a transverse groove at the base of the declivity. Dorsal outline of petiole in profile with a continuous convexity, without an anterior interruption in the outline.

Dorsum of head with fine, scattered, small punctures, the interspaces smooth and shining. Ventral surfaces of head similarly sculptured, as are the dorsal surfaces of the alitrunk, petiole and gaster. On the sides of the alitrunk striation is present, weakest on the pronotum, strongest on the metapleuron. First gastral tergite for the most part smooth between the punctures, but in places with a few weak, scratch-like striae.

This species is related to mandibularis and conjugata but is immediately separable from them by the unique structure of the propodeal declivity and the absence of striae on the ventral surfaces of the head. It is apparently known only from the type-collection consisting of a single specimen. 


\section{Plectroctena macgeei sp. n.}

(Text-figs I, 8)

Diagnosis of wORker. Mandibles edentate. First gastral tergite without a transverse groove anteriorly. Ventral surface of head without striae. Node of petiole relatively long and low, LPI < IOo.

Further description. Holotype worker. TL io.8, HL $2 \cdot 24, \mathrm{HW} 2 \cdot 00, \mathrm{CI} 89, \mathrm{ML}$ I 84 , MI 82, SL I·44, PH 0•92, PL I·04, LPI 89, DPW 0.64, DPI 67.

Internal margins of mandibles without teeth. Eyes of moderate size, ocular diameter 0.24. Funicular segments 3-9 distinctly broader than long. Propodeal laminae developed on basal half of declivity, relatively broad, broadest dorsally where they are bluntly rounded. Node of petiole in profile relatively long and low, its dorsal surface a shallow, uninterrupted convexity. In dorsal view the node long and narrow, broadening posteriorly; the posterior margin with a median impression. First gastral tergite without a transverse groove anteriorly.

All surfaces of body with numerous small, scattered punctures whose diameters are smaller than the distances separating them. The spaces between punctures smooth and shining except on the sides of the alitrunk and petiole where striae are present in the interspaces. Hairs absent except on mouthparts and gastral apex, and on the legs where they are mostly spiniform. Adult colour black with legs and antennal scapes deep red-brown.

Holotype worker, Nigeria: Gambari (Western State), 28.x.I969, amongst termites under log (B. Bolton) (BMNH).

This small species can immediately be distinguished from related forms by the combination of characters noted above in the diagnosis.

The worker captured (holotype) was walking along a U-shaped sunken path in the soil immediately below a wet-rotten, termite infested log. The nest could not be found.

\section{Plectroctena mandibularis $\mathrm{F}$. Smith}

Plectroctena mandibularis F. Smith, I858 : IoI, pl. 7, figs I-5. Syntype female (ergatoid), male, South Africa: Natal, Durban (= Port Natal) (Gueinzius) (BMNH) [examined].

Ponera caffra Spinola, I853: 70 (attributed to Klug). [Nomen nudum. Synonymy by Roger, I86I : 4I.]

Plectroctena caffra st. major Forel, I894:74. Holotype female (ergatoid; not worker), MozAMBIQUe: Delagoa (P. Berthoud). [Synonymy by Emery, I899:469.]

Plectroctena mandibularis var. integra Santschi, I924: I6r. Syntype worker, Kenya: Nairobi, Wa Kikongo et Masai, I904 (Ch. Alluaud); and syntype male, Kenya: Bura, Wa Taita, 1904 (Ch. Alluaud) (NM, Basle) [examined]. Syn. n.

Plectroctena mandibularis st. strigosa var. strialiventris Stitz, in Santschi, 1924: 162, fig. Ib.

Holotype worker, Malawi: Lake Tanganyika (Reichard) (MNHU, Berlin) [examined].

[Name not available. Variant spellings are strativentris and striativentris, loc. cit.]

Note on mandibularis types. In the original description of the species Smith gave the types as a worker and a male, but later stated that the worker was not known and that the sexes were 'taken in coitu by Herr Gueinzius', thus implying that the types were a female and a male. Emery (I899:469) pointed out this contradiction and said that in his opinion the type under discussion was a worker as it did not appear to have ocelli. However, an examination of the type shows a pair of impressions to be present at the sites of the lateral ocelli and it is concluded that this specimen is in fact an ergatoid female. 
Diagnosis of WORKer. Funicular segments $3-5$ at least as long as broad, usually distinctly longer than broad. Ocular diameter $0 \cdot 38-0 \cdot 52$. First gastral tergite without a transverse groove anteriorly. At least the ventral surface of the head with striae between the punctures; striation often present elsewhere on the head and body. Large species, HL $>3 \cdot 0$.

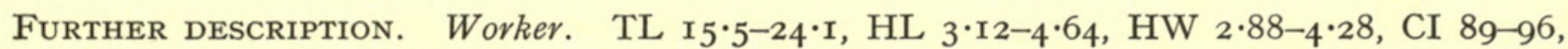
ML $2 \cdot 48-4 \cdot 12$, MI 79-93, SL $2 \cdot 16-3 \cdot 40$, PH $1 \cdot 44-2 \cdot 24$, PL I $28-2 \cdot 04$, LPI IO2-I 20, DPW I $68-\mathbf{I} \cdot 76$, DPI 80-90 (25 measured).

Basal tooth of mandible strongly developed. Palp formula 3, 4. Eyes large, ocular diameter $0.38-0.52$. Funiculus with the second segment longer than broad, segments $3-5$ usually longer than broad but quite commonly about as long as broad. Erect hairs absent from leading edge of scape. Propodeal laminae narrow or merely a pair of low ridges, never produced into teeth or spines. Pronotum often with a median longitudinal impression; in some specimens this is very weakly developed but only rarely completely absent. Petiole in profile commonly with a slight concavity or discontinuity of outline anteriorly on the dorsal surface. First gastral tergite without an anteriorly situated transverse groove or impression.

Sculpture very variable. Ventral surfaces of head and sides of alitrunk always with striae; striation usually also present upon the first and second gastral sternites. Head usually smooth and shining with scattered punctures dorsally but specimens are known in which the sides or the sides and dorsum are striate. Linking forms include individuals with the sides strongly, the dorsum weakly striate, and forms in which the median portion of the dorsum is smooth but the remainder striate. In a single specimen from Zambia only the anterior half of the dorsal head has striae. Dorsal alitrunk usually with striation, at least in part; forms with non-striate alitrunk are rare but are known from Natal. Dorsum of first and second gastral tergites range from smooth with scattered punctures to completely striate. Individuals are known in which the striation is very weak or is present on only one tergite or only on part of the tergite, and direction of gastral striation is subject to considerable variation in direction.

Female. TL $23 \cdot 6-26 \cdot 2$, HL $4 \cdot 20-4 \cdot 68$, HW $4 \cdot 20-4 \cdot 60$, CI 98-Ioo, ML $3 \cdot 68-4 \cdot 36$, MI 87-93, SL $3 \cdot 00-3 \cdot 56$, PH $2 \cdot 20-2 \cdot 36$, PL I $88-2 \cdot 08$, LPI II3-I20, DPW I $92-2 \cdot 04$, DPI 98-102 $(5$ measured).

Ergatoid, flight sclerites lacking but in some individuals vestiges of suture lines are visible in places. Very similar to largest workers but eyes larger, ocular diameter $0 \cdot 64-0 \cdot 72$, and usually lateral ocellar vestiges are present in the form of a pair of pits, which are distinctly larger and deeper than the sculptural pits.

This species is the most commonly collected member of the genus and is also one of the most variable as regards sculpturation. It has a very wide range, being known from countries of southern and eastern Africa from the Cape to Ethiopia, and occurs also in Angola and Zaire. It is very closely related to conjugata and a discussion of its separation is given under that species.

Arnold (I9I5) described the nests as follows 'The entrances to the nests are generally indicated by large heaps of earth. The chambers are placed deep below the surface, seldom less than two feet, and the number of individuals seldom exceeds 50.' He adds that the food of the species consists chiefly of millepedes and beetles but also includes termites.

\section{MATERIAL EXAMINED.}

Ethiopia: Higo Samula (R. J. Stordy); Maraquo (O. Kovacs). Uganda: Ansonga (H. Johnston). Kenya: Mombasa (Fernique); Riv. Tchania (Alluaud \& Jeannel); Diani Beach (F.X. Williams); nr Mombasa (F.X. Williams); Kisumi (?). TAnZania: Usangu distr. (S. A. Neave); Zanzibar (C. Cooke). Malawi: Lingadzi (W.A. 
Lamborn); no loc. (R. C. Wood). Zambia: Broken Hill (Silverlock). Rhodesia: Bulawayo (G. Arnold); Salisbury (G. A. K. Marshall); Lonely Mines (H. Swale); Matabeleland (J.S. Jameson); Wankie Nat. Park (W. L. Brown); Bulawayo (W.S. Brooks); Pretoria, Magalieskraal (Lingnau). Botswana: Ghanzi (J. Maurice). Mozambioue: Gaza (D. Odendaal); Vallée du Revoue d'Anorada (G. Vasse). South AFricA: Transvaal, Zoutpansberg (J. P. Cregoe); Transvaal, Shiluvane (Junod); Gomodimo (Vernay-Lang); Orange Riv. (G. B. Hamilton); Natal (ex coll. F. Smith); Natal, Estcourt (E. J. Turner); Natal (Wroughton); Pondoland, Port St. John (R. E. Turner); Pt. Elizabeth (?); Willowmore (H. Brauns); Cape Prov., Somerset East (R. E. Turner); Pretoria (Von Sassighim); Algoa Bay (H. Brauns); Zululand (I. Trägårdh). ANGola: Bruco (P. M. Hammond). ZAIre: Katanga (Lemaire); Katanga, Vallée de la Lubumbashi (Buttgenbach); Kapiri (L. Charliers); Vallée Lukuga (Schwetz); no loc. (Dybowski); Kapona (E.S. Ross E. R. E. Leech); Rutshuru (E.S. Ross \& R. E. Leech); Lualaba Riv., Bukama (J. C. Bradley).

\section{Plectroctena strigosa Emery stat. n.}

Plectroctena mandibularis var. strigosa Emery, I899: 469. Holotype worker, South AFricA: Natal (Staudinger \& Bang-Haas) (probably in MCSN, Genoa).

Diagnosis of WORKer. Similar to mandibularis but leading edges of antennal scapes with a row of short, erect, freely projecting hairs. Entire dorsum of head, alitrunk and gaster very densely, finely and closely striate.

FURTHER DESCRIPTION. Worker. TL I $5 \cdot 4-20 \cdot \mathrm{I}, \mathrm{HL} 3 \cdot 4 \mathrm{O}-4 \cdot 08$, HW 3.00-3.64, CI 87-90, ML $2 \cdot 80-3 \cdot 60$, MI $79-89$, SL $2 \cdot 60-3 \cdot 24 ;$ PH I.6o-I $\cdot 84$, PL I·40-I 68 , LPI Io2-II4, DPW I $\cdot 08-\mathrm{I} \cdot 28$, DPI 7 I-77 (Io measured).

Closely related to mandibularis and mostly matching the characters of that species, but differing as follows. Funicular segments 3-5 always notably longer than broad. Petiole tending to be somewhat narrower in dorsal view, compare DPI above with that of mandibularis, DPI 8o-9o. Leading (anterior) margin of antennal scapes with freely projecting, erect, short hairs, absent in mandibularis. Ventral margins of femora with numerous long, erect, freely projecting hairs. Punctate sculpturation everywhere on head and body secondary to a very fine, dense, usually longitudinal striation which gives the species a matt black appearance to the naked eye. In mandibularis the head and gaster are usually shiny black.

Despite the above-listed characters I am not wholly convinced that strigosa is a valid species, as mandibularis is very variable throughout its wide range. However, shortage of strigosa material at the present time and the lack of linking forms between it and mandibularis preclude a more detailed investigation. For the present, therefore, it appears best to grant specific status to strigosa until sufficient material can be accumulated to decide whether it is deserving of this status or is merely an extreme geographical variant of mandibularis.

MATERIAL EXAMined.

Kenya: Diani Beach (F. X. Williams); Mombasa (F.X. Williams); Mombasa (G. M. Allen \& G. Brooks); Diani Beach (N. L. H. Krauss); Mombasa, Kilindini (L. F. Brown). Tanzania: Morogora (A. Loveridge). 


\section{Plectroctena subterranea Arnold}

Plectroctena subterranea Arnold, 1915:84, pl. 3, figs 23, 23a. Syntype workers, female, Rhodesia: Bulawayo r4.vi.rgr3 (G. Arnold); and Shiloh (G. Arnold) (BMNH) [examined]. Myopias subterranea (Arnold); Wheeler, 1922a: $87 ; 1922 b: 785$.

Plectroctena subterranea Arnold; Santschi, 1924 : 157, I7 r.

Plectroctena punctatus Santschi, r924 : I7o. Holotype male, Kenya: Bura Wa Taita, iii. 1912, ro50 m, st. 6r (Alluaud \& Jeannel) (NM, Basle) [examined]. Syn. n.

DiAgnosis OF WORKER. Funicular segments $3-5$ broader than long. Ocular diameter 0.I4-0.20. Labial palp with 2 segments. Head without striae. Full adult colour red-brown.

FURTHER DESCRIPTION. Worker. TL, $7 \cdot 6-\mathrm{Io} \cdot 8 \mathrm{HL}$ I $60-2 \cdot 20 \mathrm{HW}$ I.40-I $\cdot 96$, CI $86-89$, ML I.28-г 76 , MI $75-80$, SL $0 \cdot 96-\mathrm{I} \cdot 24$, PH $0 \cdot 72-\mathrm{I} \cdot 04$, PL $0 \cdot 68-0 \cdot 88$, LPI I09-I 28 , DPW $0 \cdot 56-0 \cdot 80$, DPI 82-94 (6 measured).

Basal tooth of mandible well developed but the distal tooth represented only by a slightly raised angle. Funicular segments 3-9 distinctly broader than long. Labial palp 2-segmented (single worker dissected). Eyes small, ocular diameter 0.20 at maximum. Occipital margin feebly concave in full-face view, more strongly so in larger than in smaller workers. Propodeal laminae developed but without dentiform prominences. Petiole with dorsal surface uninterrupted in profile by an anterior depression or discontinuity of outline; the dorsal surface with a feeble anterior-posterior slope. In dorsal view the petiole short and broad, only slightly broader behind than in front, and with the posterior surface weakly concave. First gastral tergite without a transverse groove or impression anteriorly.

All dorsal surfaces, sides and ventre of head and gastral sternites with numerous small, fine, widely separated punctures, the spaces between which are smooth and highly polished. Sides of alitrunk and petiole with striae; the striae on the meso- and metapleurae and the sides of the propodeum so dense as to obscure the puncturation, considerably less dense or absent on part or all the sides of the pronotum.

Female. TL II 8 , HL $2 \cdot 52$, HW $2 \cdot 24$, CI $89, \mathrm{ML}$ I $92, \mathrm{MI} 76$, SL I·44, PH I·28, PL I 04 , LPI I23, DPW 0.92, DPI 88.

Alate, flight sclerites fully developed. Ocular diameter $0 \cdot 36$; ocelli present. Otherwise as worker.

This species was formerly known only from Rhodesia and Malawi but two small workers are present in the $\mathrm{MCZ}$, Cambridge collection, from the Ivory Coast savannah. One of them (a teneral) approaches the lower end of the size range quoted above but the other is very small.

The dimensions of the two are TL $5 \cdot 6,6 \cdot 7, \mathrm{HL}$ I $26, \mathrm{I} \cdot 40, \mathrm{HW}$ I $\cdot$ Io, I $\cdot 22, \mathrm{CI} 87,87, \mathrm{ML}$ 0.92, 0.98, MI 73, 70, SL 0.72, o.8o, PH o.68, o.72, PL 0.60, o.64, LPI II3, II3, DPW o.52, $0 \cdot 56$, DPI 76,87 . Ocular diameter $0 \cdot 07,0 \cdot 08$.

The sculpture is somewhat more coarse than in Rhodesian specimens, with the punctures larger and more distinctive, especially on the head and dorsal alitrunk. There is a possibility that these two specimens are in fact referable to a different species, very closely related to subterranea, but our present knowledge of the genus does not permit me to separate them.

Santschi's punctatus, based upon a single male, appears to be the male of subterranea as the holotype compares well with a damaged male of subterranea in the BMNH collection.

MATERIAL EXAMINED.

Ivory Coast: Lamto, Toumodi (J. Lévieux). Malawi: Mlanje (S. A. Neave); Chiroma Ruo (R. C. Wood). Rhodesia: Bulawayo (G. Arnold). 


\section{Plectroctena ugandensis Menozzi}

Plectroctena ugandensis Menozzi, I932:99, fig. 2. Holotype female, Uganda: Bussu (E. Bayon) (location of type not known).

Note: Professore E. Mellini (IE, Bologna) informs me that the holotype of this species cannot be found in the Menozzi collection.

I have not been able to locate the type of this species but judging from the original description I refer two specimens from MCZ, Cambridge to ugandensis. Both are alate females and as Menozzi points out, ugandensis is very closely related to subterranea. When the females of both these species are better known the two may prove to be inseparable.

Characters useful in separating the species include size (ugandensis is notably smaller) and the fact that in ugandensis the antennal scapes do not reach back to the level of the lateral ocelli, whereas in subterranea the scapes easily surpass them.

Dimensions of the two females referred to this species are: TL $9 \cdot 4-9 \cdot 8, \mathrm{HL} I \cdot 86-\mathrm{I} \cdot 88$, HW I 64 , CI 87-88, ML I·42-I·44, MI 76-77, SL I·04-I·08, PH o•86, PL o•86-0•88, LPI 98-100, DPW $0 \cdot 76$, DPI 88 . Ocular diameter $0 \cdot 30$.

Note particularly the relatively low petiole (LPI in subterranea female is 123).

MATERIAL EXAMINED.

ZAIRE: Coquilhatville (?).

A SPECIES PROPERLy EXCLUDED FROM PLECTROCTENA

Psalidomyrmex mabirensis (Arnold) comb. et stat. $\mathbf{n}$.

Plectroctena mandibularis subsp. mabirensis Arnold, 1954:293, figs 3, 3a. Syntype workers,

UGanda: Mabira Forest (G. Arnold) (probably in Bulawayo Museum, Rhodesia).

I have not examined the types of this species but from Arnold's description and figures it is apparent that the species belongs to the genus Psalidomyrmex, and is related to foveolatus André. The description of the sculpturation does not accurately fit any of the commoner species of Psalidomyrmex and for this reason, and also to remove any connection with mandibularis, mabirensis is granted new status as a good species.

\section{ACKNOWLEDGEMENTS}

I would like to express my thanks and gratitude to the following persons, who have provided material and types during the course of this revision, or who have helped in other ways. Prof. W. L. Brown Jr (Cornell University, Ithaca); Dr J. Decelle (MRAC, Tervuren); Dr E. Königsmann (MNHU, Berlin); Prof. E. Mellini (IE, Bologna); Prof. E. Tremblay (IE, Naples); Dr C. Baroni Urbani (NM, Basle); Ms J. C. White (MCZ, Cambridge). 


\section{REFERENCES}

Arnold, G. I9I5. A monograph of the Formicidae of South Africa; part I. Ann. S. Afr. Mus. 14 : I-I 59, pl. I.

1954. New Formicidae from Kenya and Uganda. Annls Mus. r. Congo belge (N.S. in $\left.4^{\circ}\right)$ zool. $1: 29$ I-295, 6 figs.

Brown, W. L. JR. 1963. Characters and synonymies among the genera of ants; part 3. Some members of the tribe Ponerini. Breviora no. 190 : I-Io.

Eidmann, H. I944. Die Ameisenfauna von Fernando Poo. Beitrag zu den Ergebnissen der Westafrika-Expedition Eidmann I939/40. Zool. Jb. Syst. 76 : 4I3-49o, I7 figs, 2 pls.

Emery, C. r89r. Voyage de M. Ch. Alluaud dans le térritoire d'Assinie (Afrique occidentale), juillet et août r886. Annls Soc. ent. Fr. $60: 553-574$, pl. I5.

1899. Fourmis d'Afrique. Annls Soc. ent. Belg. 43:459-504, figs.

I9II. In Wytsman, Genera Insect. Hymenoptera, Fam. Formicidae, subfam. Ponerinae, fasc. 118 : I25 pp., 3 pls.

Forel, A. I894. Abessinische und andere afrikanische Ameisen, gesammelt von Herrn Ingenieur Alfred Ilg, von Herrn Dr. Liengme, von Herrn Pfarrer Missionar P. Berthoud, Herrn Dr. Arth. Müller etc. Mitt. schweiz. ent. Ges. 9 : 64-1oo.

_ r9r7. Cadre synoptique actuel de la faune universelle des fourmis. Bull. Soc. vaud. Sci. nat. 51 : 229-253.

Menozzi, C. I922. Miscellanea mirmecologica. Annali Mus. civ. Stor. nat. Giacomo Doria (3) 9 [49] : 347-358, 4 figs.

1932. Raccolte mirmecologiche dell'Africa orientale conservate nel Museo Civico di Storia Naturale 'Giacomo Doria' di Genova. Parte seconda. Formiche dell'Uganda e delle Isole Sesse raccolte dal Dr E. Bayon e determinata da C. Menozzi. Annali Mus. civ. Stor. nat. Giacomo Doria 56 : 93-I I 4,4 figs.

Roger, J. I86I. Die Ponera-artigen Ameisen. Berl. ent. Z. 5 : I-54.

Santschi, F. I9ir. Nouvelles fourmis du Congo et du Benguela. Revue Zool. Bot. Afr. 1 : 204-2I7.

— r912. Fourmis d'Afrique et de Madagascar. Annls Soc. ent. Belg. 56 : 150-167, figs A-D.

I9r4a. Meddelanden från Göteborgs Musei Zoologiska Afdeling no. 3. Fourmis du Natal et du Zululand récoltées par le Dr I. Trägårdh; avec un appendice; Notes biologiques par Ivar Trägårdh. Göteborgs K. Vetensk.-o. VitterhSamh. Handl. 15 : I-47, Io figs.

— I9I $4 b$. Formicides de l'Afrique occidentale et australe du voyage de M. le Professeur F. Silvestri. Boll. Lab. Zool. gen. agv. Portici $8: 307-385,34$ figs.

- r9r9a. Cinq notes myrmécologiques. Bull. Soc. vaud. Sci. nat. 52 : 325-330, 4 figs.

r 9 I9b. Nouvelles fourmis du Congo Belge du Musée du Congo Belge, à Tervuren. Revue Zool. Bot. Afr. 7 : 79-9г.

- 1924. Revue du genre Plectroctena. Revue suisse Zool. 31 : I55-173, 3 figs.

Sмiтн, F. I858. Catalogue of hymenopterous insects in the collection of the British Museum part 6 Formicidae: 2 I6 pp., I4 pls. London.

Spinola, M. I853. Compte rendu des Hyménoptères inédits provenants du voyage entomologique de M. Ghiliani. Memorie Accad. Sci. Torino (2) 13 : I9-94.

Wheeler, W. M. I922a. Ants of the Belgian Congo, part 2. Ants collected by the American Museum Congo Expedition. Bull. Am. Mus. nat. Hist. 45 : 39-269, 23 pls, 76 figs.

- I922b. Ants of the Belgian Congo, part 8. A synonymic list of the ants of the Ethiopian Region. Bull. Am. Mus. nat. Hist. 45 : 71 I-I004. 

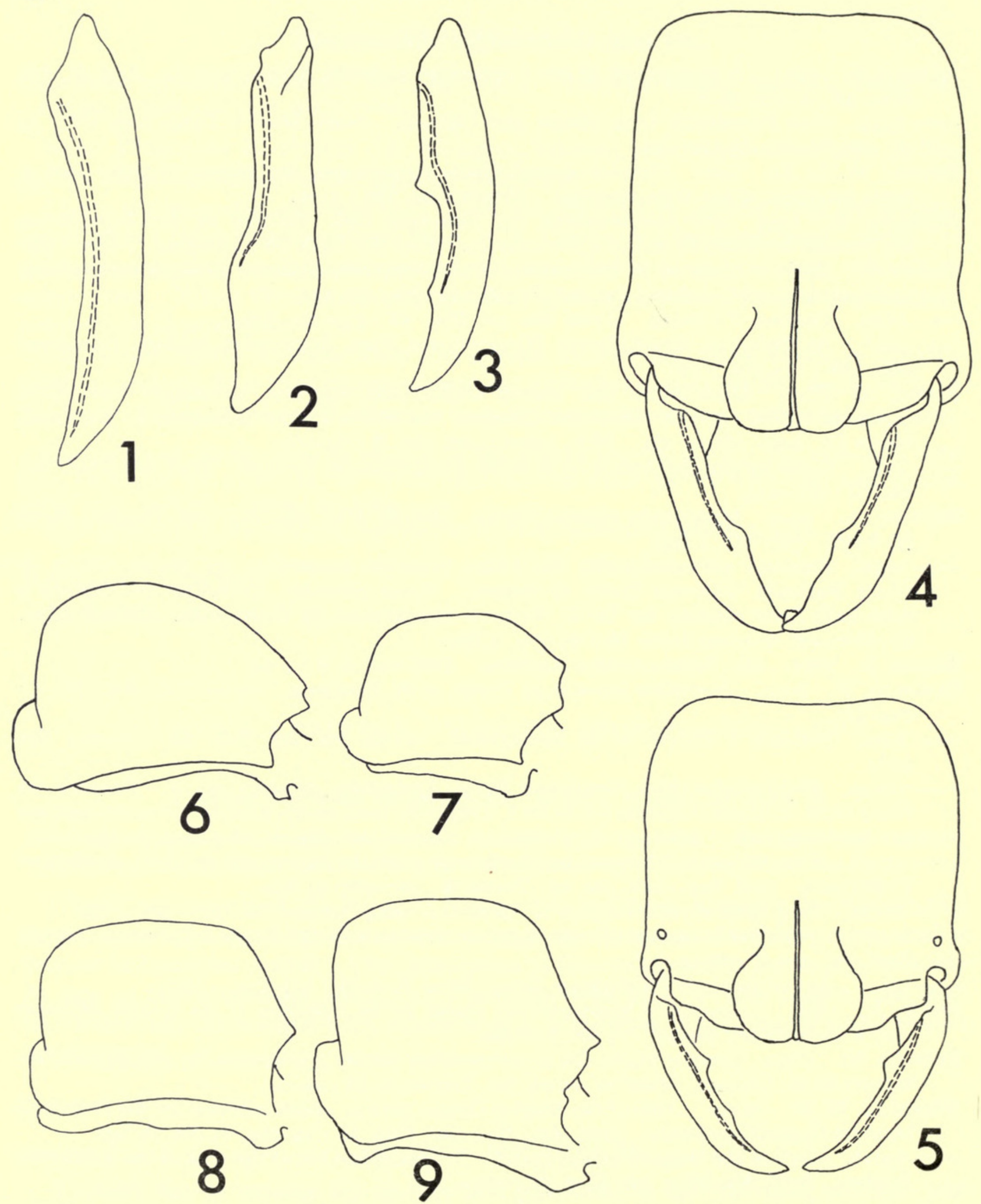

FIgS I-3. Dorsal view of left mandibular blade in workers, hairs omitted. I. macgeei, 2. hastifer, 3. minor, showing characteristic shape of mandible in the genus.

FIG. 4. Dorsal view of head of anops, pubescence and antennae omitted.

Fig. 5. Dorsal view of head of cryptica, pubescence and antennae omitted.

Figs 6-9. Lateral view of petiole in workers. Anterior face to the right; pilosity omitted. 6. hastifer, 7. anops, 8. macgeei, 9. minor. 


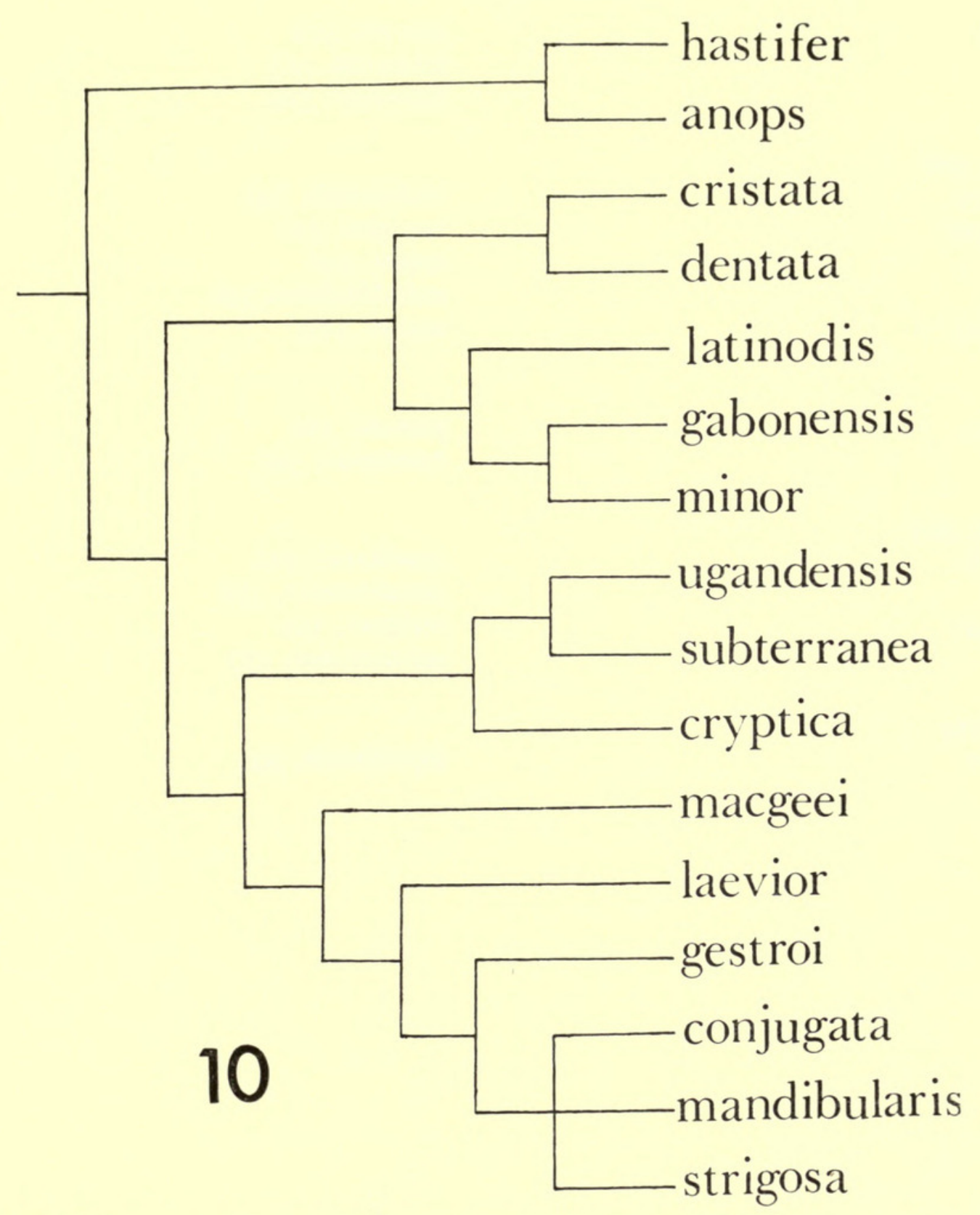

Fig. Io. Dendrogram to show affinities of species in genus Plectroctena. Lines do not imply phylogeny. 


\section{INDEX}

Synonyms are in italics.

anops, 3I9

laevior, 329

latinodis, 323

liberiana, 324

caffra, 330

conjugata, 326

cristata, $32 \mathrm{I}$

cryptica, 327

mabirensis, 334

macgeei, 330

major, 330

mandibularis, 330

dentata, 322

minor, 324

emeryi, 322

perusta, 324

punctatus, 333

gabonensis, 323

gestroi, 328

semileavis, $32 \mathrm{I}$

strialiventris, 330

hastifer, 320

strigosa, 332

subterranea, 333

insularis, 324

integra, 330

ugandensis, 334

B. Bolton, B.Sc., A.R.C.S.

Department of Entomology

British Museum (Natural History)

CROMWELl RoAD

LoNDON SW7 5 BD 


\section{$2 \mathrm{BHL}$ Biodiversity Heritage Library}

Bolton, Barry. 1974. "A revision of the ponerine ant genus Plectroctena F. Smith (Hymenoptera: Formicidae)." Bulletin of the British Museum (Natural History) Entomology 30, 309-338. https://doi.org/10.5962/bhl.part.24942.

View This Item Online: https://www.biodiversitylibrary.org/item/19430

DOI: https://doi.org/10.5962/bhl.part.24942

Permalink: https://www.biodiversitylibrary.org/partpdf/24942

\section{Holding Institution}

Natural History Museum Library, London

\section{Sponsored by}

Natural History Museum Library, London

\section{Copyright \& Reuse}

Copyright Status: In copyright. Digitized with the permission of the rights holder.

Rights Holder: The Trustees of the Natural History Museum, London

License: http://creativecommons.org/licenses/by-nc-sa/4.0/

Rights: http://biodiversitylibrary.org/permissions

This document was created from content at the Biodiversity Heritage Library, the world's largest open access digital library for biodiversity literature and archives. Visit BHL at https://www.biodiversitylibrary.org. 